\title{
Laboratory colonization and maintenance of Anopheles atroparvus from the Ebro Delta, Spain
}

\author{
Lotty Birnberg ${ }^{1}$, Carles Aranda ${ }^{1,2}$, Sandra Talavera ${ }^{1}$, Ana I. Núñez ${ }^{1}$, Raúl Escosa ${ }^{3}$ and Núria Busquets ${ }^{1 *}$ (D)
}

\begin{abstract}
Background: Historically, Anopheles atroparvus has been considered one of the most important malaria vectors in Europe. Since malaria was eradicated from the European continent, the interest in studying its vectors reduced significantly. Currently, to better assess the potential risk of malaria resurgence on the continent, there is a growing need to update the data on susceptibility of indigenous Anopheles populations to imported Plasmodium species. In order to do this, as a first step, an adequate laboratory colony of An. atroparvus is needed.

Methods: Anopheles atroparvus mosquitoes were captured in rice fields from the Ebro Delta (Spain). Field-caught specimens were maintained in the laboratory under simulated field-summer conditions. Adult females were artificially blood-fed on fresh whole rabbit blood for oviposition. First- to fourth-instar larvae were fed on pulverized fish and turtle food. Adults were maintained with a 10\% sucrose solution ad libitum.
\end{abstract}

Results: An An. atroparvus population from the Ebro Delta was successfully established in the laboratory. During the colonization process, feeding and hatching rates increased, while a reduction in larval mortality rate was observed.

Conclusions: The present study provides a detailed rearing and maintenance protocol for An. atroparvus and a publicly available reference mosquito strain within the INFRAVEC2 project for further research studies involving vectorparasite interactions.

Keywords: Anopheles atroparvus, Colonization, Malaria, Europe

\section{Background}

In Europe and the Middle East, dominant Anopheles vector species primarily belong to the Anopheles maculipennis subgroup [1]. Among its 11 Palaearctic sibling species [2, 3], An. atroparvus (van Thiel, 1927), is the most abundant and widely distributed [4]. This species inhabits coastal and inland areas throughout eastern and central Europe, the Iberian Peninsula and the UK $[1,5]$. However, its absence has been suggested in Greece, Turkey

\footnotetext{
*Correspondence: nuria.busquets@irta.cat

${ }^{1}$ Centre de Recerca en Sanitat Animal (CReSA), Institut de recerca en Tecnologies Agroalimentaries (IRTA), Barcelona, Spain

Full list of author information is available at the end of the article
}

[6] and partially in southern Italy where it is replaced in coastal areas by $A n$. lanbranchiae [7]. Immature stages of An. atroparvus mostly inhabit a variety of permanent or semi-permanent water bodies characterized by clear standing, or slow flowing, brackish and/or fresh water. They are commonly collected along river and lake margins, marshes, irrigation canals and especially in rice fields (primary larval habitat), where aquatic vegetation provides protection from predators and a cooler environment $[8,9]$. Anopheles atroparvus has been described as an endophilic, most commonly endophagic, and zoophilic species with a marked preference for domestic farm animals [10-14]. Due to its association to human

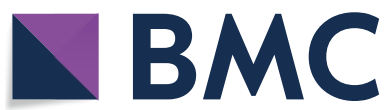

(c) The Author(s) 2020. This article is licensed under a Creative Commons Attribution 4.0 International License, which permits use, sharing, adaptation, distribution and reproduction in any medium or format, as long as you give appropriate credit to the original author(s) and the source, provide a link to the Creative Commons licence, and indicate if changes were made. The images or other third party material in this article are included in the article's Creative Commons licence, unless indicated otherwise in a credit line to the material. If material is not included in the article's Creative Commons licence and your intended use is not permitted by statutory regulation or exceeds the permitted use, you will need to obtain permission directly from the copyright holder. To view a copy of this licence, visit http://creativeco mmons.org/licenses/by/4.0/. The Creative Commons Public Domain Dedication waiver (http://creativecommons.org/publicdomain/ zero/1.0/) applies to the data made available in this article, unless otherwise stated in a credit line to the data. 
settlements, An. atroparvus also demonstrates anthropophilic behavior [1].

Historically, An. atroparvus was implicated in the transmission of local strains of both Plasmodium vivax [9] and P. falciparum [8]. A recent study in which DNA was recovered from historic blood slides of patients infected during the 40's showed that both $P$. vivax and $P$. falciparum were circulating at Ebro Delta (Spain) [15], an area where An. atroparvus is the only anopheline species recorded $[15,16]$. Moreover, susceptibility tests demonstrated that different European populations were capable of transmitting imported $P$. vivax [17] and $P$. ovale strains [18], but were, to some degree, refractory to tropical $P$. falciparum strains $[17,19,20]$.

Currently, despite the situation that most of the European continent demonstrates "anophelism without malaria" [8], significant increases in the number of imported cases [5], sporadic episodes of local transmission in some countries [21-27], and predictions that climatic change could increase the risk of malaria transmission $[4,9,28,29]$ have raised new concerns for the reintroduction of malaria.

To better assess the potential risk of malaria resurgence in Europe, it is necessary to conduct vector competence studies to establish the vector-parasite relationships between local populations of Anopheles mosquitoes with the most commonly imported Plasmodium species. Consequently, as a first step, the aim of the present study was to establish a laboratory colony of An. atroparvus from the Ebro Delta, a former malaria endemic area of Spain, and provide a detailed rearing protocol for further malaria research.

\section{Methods}

\section{Study area}

The Ebro Delta is one of the most relevant ecosystems in the Western Mediterranean. It is located in Tarragona Province (Catalonia-Spain) and covers 320 square kilometers. The Ebro River divides the delta plain into two regions, the Baix Ebre from the north, with its capital Tortosa; and the Montsià from the south, with its capital Amposta. The delta is characterized by highly diverse aquatic habitats, e.g. marshes, wetlands, ponds and lakes that co-occur with densely populated areas and croplands, mostly intended for rice cultivation. The dominance of water systems in the Ebro Delta have favored the proliferation of vector mosquito species, e.g. An. atroparvus which was previously incriminated as a primary malaria vector [28].

\section{Field mosquito collections}

To start the laboratory colony, adult anopheline mosquitoes were collected weekly between August and
September 2017. In rice growing areas from the municipality of Amposta $\left(40^{\circ} 42^{\prime} 32.5686^{\prime \prime} \mathrm{N}, 0^{\circ} 35^{\prime} 12.2814^{\prime \prime} \mathrm{E}\right)$, resting male and female mosquitoes were collected in an unused shed using mouth aspirators (John W. Hock Company, Gainesville, FL, USA), placed in $30 \times 30 \times$ $30 \mathrm{~cm}$ BugDorm (Bioquip, Rancho Dominguez, CA, USA) insect rearing cages and transported live to the laboratory.

\section{Laboratory mosquito rearing protocol}

At the Institut de Recerca i Tecnologies Agroalimentaries - Centre de Recerca en Sanitat Animal (IRTACReSA) biosafety level 2 facilities (BSL2), a sterile 10\% sucrose solution was provided to wild-caught adults by placing a $50 \mathrm{ml}$ glass bottle of the solution containing a filter paper fan for mosquitoes to feed ad libitum. Ten percent $(10 / 100)$ of the captured females were dissected to determine gravid rates. Since all the dissected females were gravid, a Petri dish filled with dechlorinated tap water was placed inside the cages for oviposition. Since no eggs were laid during the first week, several artificial blood meals were offered. Field-collected females were provided blood meals on fresh whole rabbit blood (supplied by a local slaughterhouse) for $3 \mathrm{~h}$ at dusk using the Hemotek feeding system (Discovery Workshop, Accrington, UK) set at $37.5 \pm 0.5{ }^{\circ} \mathrm{C}$ and Parafilm as a feeding membrane. On day 1 post-feeding, a Petri dish containing dechlorinated tap water for oviposition was placed inside the cages and kept until eggs were laid. Egg batches were transferred to sterile plastic trays $(22 \times 15 \times 6 \mathrm{~cm})$ containing $500 \mathrm{ml}$ of dechlorinated and oxygenated tap water. One-fourth Gayelord Hauser Superlevure brewer's yeast tablet was added to stimulate hatching. To confirm the identity of this mosquito population, 25 wild-caught females (that fed and oviposited) were molecularly analyzed by polymerase chain reaction (PCR) [30].

Upon hatching, up to 100 first-instar larvae (L1) were transferred to sterile plastic trays $(22 \times 15 \times 6 \mathrm{~cm})$ containing $500 \mathrm{ml}$ of dechlorinated and oxygenated tap water. Larvae (L1 to L4), were fed $0.1 \mathrm{~g}$ minced Tetra Goldfish Flakes and Tetra ReptoMin Sticks (1:1) mixture. Water from rearing trays and food supply were replaced daily.

Pupae were collected daily using a $3 \mathrm{ml}$ plastic pipette and deposited in sterile plastic cups $(9 \mathrm{~cm}$ in diameter per $7 \mathrm{~cm}$ height) containing dechlorinated and oxygenated tap water. Cups containing F1 pupae, were placed inside $30 \times 30 \times 30 \mathrm{~cm}$ BugDorm (Bioquip) insect cages with a density of 500 specimens per cage. Adults were provided a $10 \%$ sucrose solution ad libitum as previously described.

Rearing procedures were followed for subsequent generations with slight modifications: (i) ten day-old (or 
older) females were deprived sucrose for $48 \mathrm{~h}$ and provided blood meals as described above, blood-fed females were placed in a separate cage after feeding; (ii) the oviposition Petri dish with dechlorinated tap water was placed in the cage containing blood-fed mosquitoes at day 5 post-feeding; and (iii) water from larval trays was replaced every 2 days during development. The day the water was not changed, $100 \mathrm{ml}$ of oxygenated and dechlorinated tap water was added to oxygenate and maintain water level. Larval food was added daily.

The life-cycle of An. atroparvus mosquitoes was monitored under controlled laboratory conditions simulating field summer conditions of their original habitat (temperature: $25-20^{\circ} \mathrm{C}$ for day and night respectively, relative humidity: $80 \%$, and a photoperiod: $12 \mathrm{~h}$ light: $11 \mathrm{~h}$ dark with two $30 \mathrm{~min}$ crepuscular periods).

\section{Colony assessment}

Hatching, larval mortality and feeding rates were calculated and, larval and pupal development times were determined to evaluate laboratory adaptation of the colony. The hatching rate (HR) was calculated as the proportion of L1 larvae/number of eggs. Larval mortality rate (LMR) was calculated as the total number of pupae/ L1 larvae. Feeding rate (FR) was calculated as the number of engorged females/the total number of females at the time of blood-feeding. Larval and pupal development times were calculated, respectively, as the number of days between L1 to pupae, and from pupae to adult emergence. Since most comprehensive data were obtained from the second generation (F2), hatching, feeding and mortality rates were calculated from this time point onwards. For larval and pupal development times, data from the fourth generation (F4) onwards were used. The purity of the colony was molecularly verified by PCR [30] analyzing 10 females from both, F6 and F10.

\section{Results and discussion}

An indigenous An. atroparvus population from Amposta (the Ebro Delta) was successfully colonized in our laboratory and its rearing protocol standardized. The colony constitutes one of the reference mosquito strains available within the INFRAVEC2 project for vector research.

Approximately $20 \%$ of 10-day-old females from generations F2-F6 fed on rabbit blood provided by an artificial (Parafilm) membrane. However, the feeding rates increased up to $45 \%$ in later generations (F9) (Fig. 1a). Eggs were oviposited on day 5 post-blood feeding and eggs hatched after 1-2 days. In early generations (F2-F4), between $48-55 \%$ of the eggs hatched, while in later generations, hatching rates increased to $75-92 \%$ (Fig. 1b). The increase in hatching rates reflects the successful

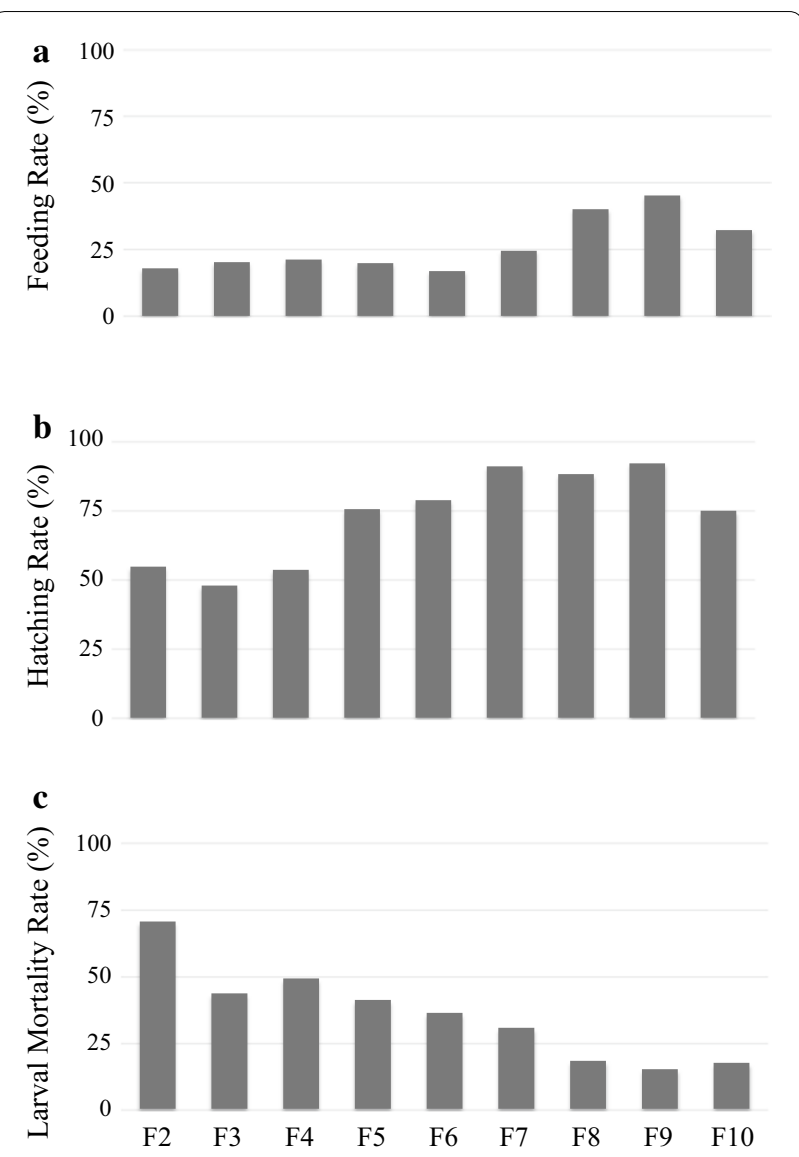

Fig. 1 Development of Anopheles atroparvus collected from the Ebro Delta under controlled laboratory conditions. a Feeding rate (FR), engorged females/total number of females at the time of feeding. $\mathbf{b}$ Hatching rate $(H R)$, total number of L1/total number of eggs. $\mathbf{c}$ Larval mortality rate (LMR), total number of pupae/total number of $L 1$

adaptation of male-mating activity as reported for other free-mating culicids [31, 32].

Throughout laboratory colonization, a clear reduction in larval mortality was observed, from $70 \%$ in F2, to less than $20 \%$ in the latest generations (Fig. 1c), with more than $80 \%$ of the first instars reared to adults. The mortality of pupae was almost null in all generations. Both, larval and pupal development times were variable. On average, 13-16 days were required from L1 to pupae (larval development time), and between 1-3 days from pupae to adult emergence (pupal development time) (Table 1). A 1:1.14 female:male ratio was observed. Adult lifespan in our laboratory under field-simulated conditions surpassed nine weeks, enough time to conduct vector competence and susceptibility assays. The stenogamic behavior described for Spanish populations [13] was confirmed in the An. atroparvus colony and under laboratory conditions males successfully mated with females in small cages. Swarming and mating events were observed 
Table 1 Development times in immature stages of Anopheles atroparvus during laboratory colonization

\begin{tabular}{lll}
\hline Generation & \multicolumn{2}{l}{ Development time (days) } \\
\cline { 2 - 3 } & Larva to pupa & Pupa to adult \\
\hline F2 & $9-25$ & na \\
F3 & $9-25$ & na \\
F4 & $8-22$ & $1-3$ \\
F5 & $12-25$ & $1-4$ \\
F6 & $11-24$ & $1-4$ \\
F7 & $10-26$ & $2-4$ \\
F8 & $8-22$ & $1-3$ \\
F9 & $10-21$ & $1-3$ \\
F10 & $10-18$ & $1-3$ \\
\hline
\end{tabular}

Abbreviation: na, data not available

during blood feeding, contradicting previous behavioral descriptions [8]. Egg development and development times of immature stages observed under the present laboratory conditions were in agreement with previous studies that used similar temperatures [8], showing the relevance of this variable during colonization attempts of vector mosquito species.

Finally, that the diagnostic PCR methods described by Proft et al. [30] for the identification of six sibling species of the Maculipennis subgroup resulted in the amplification of three fragments per individual, which corresponded in size to An. atroparvus (117 bp), An. melanoon (224 bp) and An. labranchiae (374 bp). However, after sequencing, all three PCR products corresponded to gene sequences of $A n$. atroparvus. Based on our experience [16], $A n$. atroparvus is the only anopheline species distributed in this area and these findings suggest that the single 3'-end nucleotide substitution in the primer annealing sites, in the case of $A n$. melanoon and $A n$. labranchiae, does not provide a unique diagnostic gene fragment for the An. atroparvus population studied.

\section{Conclusions}

The present study provides a detailed protocol used to successfully establish and maintain a laboratory colony of a European strain of An. atroparvus. Field-caught specimens were only fed via artificial membrane feedings, facilitating the logistics during colony maintenance and during vector competence studies. The potential to evaluate pathogen susceptibility using artificial blood-feeding techniques of earlier laboratory generations would provide a more accurate assessment of vector competence of wild populations.

\section{Abbreviations}

HR: hatching rate; LMR: larval mortality rate; FR: feeding rate; L1: first-instar larva; L2: second-instar larva; L4: fourth-instar larva.

\section{Acknowledgements}

We would like to thank the personnel from the Consorci de Polítiques Ambientals de les Terres de l'Ebre (COPATE) for their support and guidance during field work. We are grateful to Drs Mark Benedict and Paul Howell from the MR4 for sharing their expertise in mosquito breeding.

\section{Authors' contributions}

NB, LB, ST and CA conceived and designed the study. NB, LB, CA, RE and AN conducted the field work and mosquito captures. $L B$ conducted mosquito rearing and maintenance. NB acquired funding, administrated the project and supervised mosquito rearing. LB wrote the first draft of the manuscript. All co-authors revised final version. All authors read and approved the final manuscript.

\section{Funding}

This research was funded by the European Commission, Horizon 2020 Infrastructures \#731060 Infravec2 project.

\section{Availability of data and materials}

All data generated or analyzed during this study are included in the article.

Ethics approval and consent to participate

Not applicable.

\section{Consent for publication}

Not applicable.

\section{Competing interests}

The authors declare that they have no competing interests.

\section{Author details}

${ }^{1}$ Centre de Recerca en Sanitat Animal (CReSA), Institut de recerca en Tecnologies Agroalimentaries (IRTA), Barcelona, Spain. ${ }^{2}$ Servei de Control de Mosquits del Consell Comarcal del Baix Llobregat, Barcelona, Spain. ${ }^{3}$ Consorci de

Polítiques Ambientals de les Terres de l'Ebre (COPATE), Tarragona, Spain.

Received: 30 April 2020 Accepted: 29 July 2020

Published online: 03 August 2020

\section{References}

1. Sinka ME, Bangs MJ, Manguin S, Coetzee M, Mbogo CM, Hemingway J. et al. The dominant Anopheles vectors of human malaria in Africa, Europe and the Middle East: occurrence data, distribution and bionomic précis. Parasit Vectors. 2010;3:117.

2. Linton YM, Smith L, Koliopoulos G, Zounos AK, Samanidou-Voyadjoglou A, Patsoula E. The Anopheles (Anopheles) maculipennis complex (Diptera: Culicidae) in Greece. J Nat His. 2007;41:2683-99.

3. Harbach RE. The phylogeny and classification of Anopheles. In: Manguin S, editor. Anopheles mosquitoes - new insights into malaria vectors. London, UK: IntechOpen; 2013. p. 4-55.

4. Hertig E. Distribution of Anopheles vectors and potential malaria transmission stability in Europe and the Mediterranean area under future climate change. Parasit Vectors. 2019;12:18.

5. Piperaki ET, Daikos GL. Malaria in Europe: emerging threat or minor nuisance? Clin Microbiol Infect. 2016;22:6.

6. Odolini S, Gautret P, Parola P. Epidemiology of imported malaria in the Mediterranean region. Mediterr J Hematol Infect Dis. 2012;4:e2012031.

7. Romi R, Pontuale G, Sabatinelli G. Le zanzare italiane: generalità e identificazione degli stadi preimaginali (Diptera: culicidae). Fragmenta Entomol. 1997;29(Suppl. 1):1-141.

8. Jetten TH, Takken W. Anophelism without malaria in Europe: a review of the ecology and distribution of the genus Anopheles in Europe. Wageningen Agr Univ Pap. 1994;94:5.

9. Bueno-Mari R, Jiménez-Peydró R. Study of the malariogenic potential of eastern Spain. Trop Biomed. 2012;29:39-50. 
10. Brugman VA, Hernández-Triana LM, England ME, Medlock JM, Mertens PPC, Logan JG, et al. Blood-feeding patterns of native mosquitoes and insights into their potential role as pathogen vectors in the Thames estuary region of the United Kingdom. Parasit Vectors. 2017;10:163.

11. Martínez de la Puente J, Ruiz S, Soriguer R, Figuerola J. Effect of blood meal digestion and DNA extraction protocol on the success of blood meal source determination in the malaria vector Anopheles atroparvus. Malar J. 2013;12:109.

12. Lourenço PM, Sousa CA, Seixas J, Lopes P, Novo MT, Almeida APG Anopheles atroparvus density modelling using MODIS NDVI in a former malarious area in Portugal. J Vec Ecol. 2011;36:279-91.

13. Bueno-Mari R, Jiménez-Peydró R. Pueden la malaria y el dengue reaparecer en Europa? Gac Santi. 2010;24:347-53.

14. Kampen $\mathrm{H}$, Schäfer M, Zielke DE, Walther D. The Anopheles maculipennis complex (Dipera: Culicidae) in Germany: an update following recent monitoring activities. Parasitol Res. 2016;115:3281-94.

15. Gelabert P, Sandoval-Velasco M, Olalde I, Fregel R, Rieux A, Escosa R, et al. Mitochondrial DNA from the eradicated European Plasmodium vivax and P. falciparum from 70-year-old slides from the Ebro Delta in Spain. Proc Ntnl Acad Sci USA. 2016:113:11495-500.

16. Bargues MD, Latorre JM, Morchon R, Simon F, Escosa R, Aranda C, et al. RDNA sequences of Anopheles species from the Iberian Peninsula and an evaluation of the 18S rRNA gene as phylogenetic marker in Anophelinae. J Med Entomol. 2006;43:508-17.

17. Daskova NG, Rasnicyn SP. Review of data on susceptibility of mosquitoes in the URSS to imported strains of malaria parasites. Bull World Health Organ. 1982:60:893-7.

18. Garnham PCC, Bray RS, Cooper W, Lainson R, Awad FI, Williamson J. Preerythrocytic stages of human malaria: Plasmodium ovale a preliminary note. Br Med J. 1954;1:257.

19. Ramsdale CD, Coluzzi M. Studies on the infectivity of tropical African strains of Plasmodium falciparum to some southern European vectors of malaria. Geneva: World Health Organization; 1975.

20. Zuleta J, Ramsdale CD, Coluzzi M. Receptivity to malaria in Europe. Bull World Health Organ. 1975;52:109-11.

21. Santa-Olalla P, Vázquez-Torres MC, Latorre-Fandós E, Mairal-Claver $\mathrm{P}$, Cortina-Solano P, Puy-Azón A, et al. First autochthonous malaria case due to Plasmodium vivax since eradication, Spain, October 2010. Euro Surveill. 2010;15:19684.

22. Kruger A, Rech A, Su XZ, Tannich E. Two cases of autochthonous Plasmodium falciparum malaria in Germany with evidence for local transmission by indigenous Anopheles plumbeus. Trop Med Int Health. 2001;6:983-5.
23. Arends JE, Oosterheert JJ, Kraaij-Dirkzwager MM, Kaan JA, Fanoy EB, Haas PJ, et al. Two cases of Plasmodium falciparum malaria in the Netherlands without recent travel to a malaria-endemic country. Am J Trop Med Hyg. 2013;89:527-30.

24. Armengaud A, Legros F, D'Ortenzio E, Quatresous I, Barre H, Houze S, et al. A case of autochthonous Plasmodium vivax malaria, Corsica, August 2006. Travel Med Infect Dis. 2008;6:36-40.

25. Baldari M, Tamburro A, Sabatinelli G, Romi R, Severini C, Cuccagna G, et al. Malaria in Maremma, Italy. Lancet. 1998;351:1246-7.

26. Danis K, Baka A, Lenglet A, Van Bortel W, Terzaki I, Tseroni M, et al. Autochthonous Plasmodium vivax malaria in Greece, 2011. Euro Surveill. 2011;16:19993.

27. Doudier B, Bogreau H, DeVries A, Ponçon N, Stauffer WM, Fontenille D, et al. Possible autochthonous malaria from Marseille to Minneapolis. Emerg Infect Dis. 2007;13:1236-8.

28. Sainz-Elipe S, Latorre JM, Escosa R, Masià M, Fuentes MV, Mas-Coma S, et al. Malaria resurgence risk in southern Europe: climate assessment in a historically endemic area of rice fields at the Mediterranean shore of Spain. Malar J. 2010;9:2211.

29. Capinha C, Gomes E, Reis E, Rocha J, Sousa CA, do Rosário VE, et al. Present hábitat suitability for Anopheles atroparvus (Diptera: Culicidae) and its coincidence with former malaria areas in mainland Portugal. Geospat Health. 2009;3:177-87.

30. Proft J, Maier WA, Kampen $\mathrm{H}$. Identification of six sibling species of the Anopheles maculipennis complex (Diptera: Culicidae) by a polymerase chain reaction assay. Parasitol Res. 1999;85:837-43.

31. Hoshino K, Isawa H, Tsuda Y, Kobayashi M. Laboratory colonization of Aedes japonicus japonicus (Diptera: Culicidae) collected in Narita, Japan and biological properties of the established colony. Jpn J Infect Dis. 2010;63:401-4

32. Lima JBP, Valle $D$, Peixoto AA. Adaptation of a South American malaria vector to laboratory colonization suggests faster-male evolution for mating ability. Evol Biol. 2004;4:12

\section{Publisher's Note}

Springer Nature remains neutral with regard to jurisdictional claims in published maps and institutional affiliations.
Ready to submit your research? Choose BMC and benefit from:

- fast, convenient online submission

- thorough peer review by experienced researchers in your field

- rapid publication on acceptance

- support for research data, including large and complex data types

- gold Open Access which fosters wider collaboration and increased citations

- maximum visibility for your research: over 100M website views per year

At BMC, research is always in progress.

Learn more biomedcentral.com/submissions 